\title{
Pengaruh Induksi Resistensi oleh Khamir Candida tropicalis terhadap Pertumbuhan Tanaman Cabai Terinfeksi Colletotrichum acutatum
}

\author{
Sri Hartati ${ }^{1}$, Linda Tarina ${ }^{2}$, Endah Yulia ${ }^{1}$ dan Luciana Djaya ${ }^{1}$ \\ ${ }^{1}$ Departemen Hama dan Penyakit Tumbuhan, Fakultas Pertanian, Universitas Padjadjaran \\ ${ }^{2}$ Program Studi Agroteknologi, Fakultas Pertanian, Universitas Padjadjaran \\ *Alamat korespondensi: s.hartati@unpad.ac.id
}

\begin{abstract}
Effect of induced resistance by Candida tropicalis on the growth of chili plants infected by Colletotrichum acutatum
\end{abstract}

Colletotrichum acutatum is a major pathogen of chili that causes a big yield loss. Candida tropicalis has been reported as a biocontrol agent antagonistic to $C$. acutatum. The research was objected to find out the effect of induced resistance by $C$. tropicalis on the growth of chili plants infected by $C$. acutatum. The application of the yeast was carried out by seed dipping and seedling spraying methods. As treatments, $C$. acutatum, the pathogen was inoculated at different time, i.e. $\mathrm{A}=$ inoculation at 3 days after the induction (dai) by C. tropicalis, $\mathrm{B}=$ inoculation at 7 dai, $\mathrm{C}=$ inoculation at 10 dai, $\mathrm{D}=$ positive control on inoculation at 3 dai, $\mathrm{E}=$ positive control on inoculation at 7 dai, $F=$ positive control on inoculation at 10 dai, $G=$ negative control with no induction nor inoculation. The results showed that the induction by $C$. tropicalis was able to increase the plant height, leaf number, and dry weight. The highest increase of plant height of $30.72 \%$ was caused by induction of C. tropicalis inoculated at 7 dai. Induction of C. tropicalis inoculated at 3 dai increased the leaf number by $49.47 \%$, and the plant dry weight by $50 \%$. $C$. tropicalis has a potency to be developed as plant growth inducer.

Keywords: Antagonist, Inoculation, Fungi, Yeast

\begin{abstract}
ABSTRAK
Jamur Colletotrichum acutatum merupakan patogen penyebab kehilangan hasil panen yang cukup besar pada tanaman cabai. Salah satu mikrob antagonis jamur ini yang telah dilaporkan adalah khamir Candida tropicalis. Penelitian ini bertujuan untuk mengetahui pengaruh induksi resistensi oleh C. tropicalis terhadap pertumbuhan tanaman cabai terinfeksi C. acutatum. Penelitian dilaksanakan dengan menggunakan teknik perendaman benih dan penyiraman bibit tanaman cabai menggunakan suspensi $C$. tropicalis dengan waktu inokulasi patogen $C$. acutatum yang berbeda. Perlakuan tersebut adalah $\mathrm{A}=$ Inokulasi $C$. acutatum 3 hari setelah perlakuan induksi $C$. tropicalis (hsp), B = Inokulasi $C$. acutatum 7 hsp, C = Inokulasi $C$. acutatum 10 hsp, D = Kontrol (+) dengan inokulasi $C$. acutatum 3 hsp, $\mathrm{E}=$ Kontrol (+) dengan inokulasi $C$. acutatum 7 hsp, $\mathrm{F}=$ Kontrol (+) dengan inokulasi $C$. acutatum $10 \mathrm{hsp}, \mathrm{G}=$ Kontrol (-) tanpa induksi dan inokulasi. Hasil penelitian menunjukkan bahwa perlakuan induksi resistensi oleh khamir $C$. tropicalis mampu meningkatkan tinggi, jumlah daun, dan bobot kering tanaman cabai. Kemampuan meningkatkan tinggi tanaman cabai tertinggi terjadi pada perlakuan $C$. tropicalis dengan waktu inokulasi 7 hsp yaitu sebesar 30,72\%. Perlakuan khamir C. tropicalis dengan inokulasi patogen 3 hsp mampu meningkatkan jumlah daun tanaman cabai sebesar 49,47\%. Perlakuan C. tropicalis dengan waktu inokulasi 3 hsp mampu meningkatkan bobot kering tanaman sebesar 50\%. Khamir C. tropicalis berpotensi untuk dikembangkan sebagai agens pemacu pertumbuhan tanaman.
\end{abstract}




\section{PENDAHULUAN}

Cabai (Capsicum annuum L.) merupakan komoditas hortikultura penting dan memiliki nilai ekonomi tinggi di Indonesia (Syukur dkk., 2011). Komoditas ini sangat dibutuhkan untuk memenuhi kebutuhan sayuran segar maupun dalam industri pangan nasional. Tanaman cabai dapat dikembangkan baik di dataran tinggi maupun dataran rendah (Syukur dkk., 2011).

Produktivitas cabai di Indonesia dari tahun 2015 sampai 2017 mengalami penurunan dari 8,65 ton/ha pada tahun 2015, menjadi 8,47 ton/ha pada tahun 2016, dan 8,46 ton/ha pada tahun 2017 (Badan Pusat Statistik dan Direktorat Jenderal Hortikultura, 2018). Produktivitas cabai yang rendah dipengaruhi oleh beberapa faktor pembatas seperti perubahan iklim dan faktor lingkungan, serta gangguan organisme pengganggu tanaman (OPT). Faktorfaktor pembatas tersebut dapat memengaruhi pertumbuhan yang akhirnya berpengaruh terhadap produksi tanaman cabai. OPT penting pada tanaman cabai adalah Colletotrichum spp. penyebab penyakit antraknosa. Salah satu spesies Colletotrichum yang sering ditemukan di Jawa Barat adalah Colletotrichum acutatum.

Khamir merupakan salah satu mikrob yang memiliki kemampuan sebagai agens antagonis. Beberapa penelitian menunjukkan keberhasilan penggunaan khamir sebagai agens biokontrol terhadap patogen tanaman. Haïssam (2011) melaporkan bahwa Pichia anomala strain $\mathrm{K}$ memiliki aktivitas antagonisme yang tinggi terhadap B. cinerea dan Penicillium expansum pada apel. Khamir Debaryomyces hansenii menunjukkan aktivitas antagonisme dengan spektrum luas (Sharma et al., 2009).

Beberapa khamir dilaporkan dapat menginduksi resistensi tanaman. Khamir Pichia guilliermondii mampu menginduksi resistensi tanaman cabai untuk menekan penyakit antraknosa yang disebabkan oleh Colletotrichum capsici (Nantawanit et al., 2010). Khamir Rhodotorula sp. dilaporkan mampu menginduksi resistensi tanaman kentang untuk mengendalikan serangan virus $\mathrm{Y}$ (Alani et al., 2013). Ekstrak dinding sel khamir dilaporkan mampu menginduksi resistensi tanaman Arabidopsis thaliana dan kubis untuk menekan penyakit antraknosa dan bercak daun bakteri (Narusaka et al., 2015).

Peran khamir terhadap pertumbuhan tanaman juga telah dilaporkan. Ignatova et al., (2015) melaporkan bahwa khamir Aureobasidium pullulans dapat menghasilkan hormon pertumbuan Indole-3-Acetic Acid (IAA). Rhodotorula minuta juga telah dilaporkan mampu menghasilkan hormon pertumbuhan IAA (Nassar et al., 2005).

Khamir Candida tropicalis yang diisolasi dari buah cabai telah diketahui mampu menekan $C$. acutatum secara in vitro dan mengendalikan penyakit antraknosa pada cabai sebesar $68,20 \%$ melalui mekanisme hiperparasitisme, pembentukan senyawa volatil $(34,51 \%)$, pembentukan enzim kitinolitik (indeks kitinolitik 1,4) dan enzim ACC deaminase (Hartati, 2016). Kemampuan spesies khamir tersebut dalam meningkatkan pertumbuhan tanaman melalui mekanisme induksi resistensi belum diketahui. Penelitian ini bertujuan untuk mengetahui pengaruh induksi resistensi oleh khamir C. tropicalis terhadap pertumbuhan tanaman cabai yang terinfeksi $C$. acutatum.

\section{BAHAN DAN METODE}

Penelitian dilaksanakan di Laboratorium Bioteknologi Proteksi Tanaman, Departemen Hama dan Penyakit Tumbuhan, dan rumah kaca Kebun Percobaan Ciparanje, Fakultas Pertanian, Universitas Padjadjaran. Penelitian dilaksanakan dengan menggunakan Rancangan Acak Kelompok (RAK) dengan 7 perlakuan dan 4 ulangan. Masing-masing ulangan menggunakan 6 tanaman. Perlakuan pada penelitian ini menggunakan teknik perendaman benih dan penyiraman bibit cabai pada saat pindah tanam yaitu pada umur empat minggu, dengan menggunakan suspensi $C$. tropicalis dengan waktu inokulasi patogen $C$. acutatum yang berbeda. Perlakuan tersebut adalah sebagai berikut:

$\mathrm{A}=C$. tropicalis dengan waktu inokulasi 3 hari setelah perlakuan induksi (hsp)

$\mathrm{B}=$ C. tropicalis dengan waktu inokulasi 7 hari setelah perlakuan induksi (hsp)

$\mathrm{C}=$ C. tropicalis dengan waktu inokulasi 10 hari setelah perlakuan induksi (hsp)

$\mathrm{D}=$ Kontrol $(+)$ dengan waktu inokulasi 3 hari setelah perlakuan induksi (hsp)

$\mathrm{E}=$ Kontrol $(+)$ dengan waktu inokulasi 7 hari setelah perlakuan induksi (hsp)

$\mathrm{F}=$ Kontrol $(+)$ dengan waktu inokulasi 10 hari setelah perlakuan induksi (hsp)

$\mathrm{G}=$ Kontrol (-) tanpa induksi dan inokulasi

\section{Penyediaan C. tropicalis dan C. acutatum}

Spesies khamir C. tropicalis diperoleh dari tanaman cabai di Lumajang, sedangkan isolat $C$. acutatum diperoleh dari pertanaman cabai di 
Sumedang. Khamir diremajakan dalam media Yeast Malt Extract broth (YMB), selanjutnya ditumbuhkan pada media Potato Dextrose Agar (PDA). Isolat C. acutatum ditumbuhkan pada media PDA. Koloni khamir yang tumbuh selanjutnya disuspensikan dalam akuades steril. Kerapatan sel khamir yang digunakan $10^{8} \mathrm{sel} / \mathrm{ml}$. Kerapatan sel khamir tersebut didapatkan dengan membuat seri pengenceran suspensi khamir, selanjutnya dihitung dengan menggunakan hemositometer. Pembuatan suspensi C. acutatum dilakukan seperti pada pembuatan suspensi khamir, dengan kerapatan konidia $10^{6}$ konidia/ml.

\section{Persiapan Benih Cabai}

Benih cabai yang digunakan dalam penelitian ini adalah varietas Unpad CB-2 yang diperoleh dari Laboratorium Pemuliaan Tanaman dan Produksi Tanaman yang merupakan koleksi Dr. Ir. Neni Rostini, MS. Tanaman cabai varietas Unpad CB-2 merupakan salah satu varietas unggulan Unpad, hasil persilangan Capsicum frutescens degan varietas UNPAD $\mathrm{CB} \quad 1$ yang keturunannya disilangkan dengan cabai keriting lokal kode seleksi 1-7-2-2 atau RM08 AXKRTRM 1B (Kementerian Pertanian., 2015).

\section{Perlakuan induksi}

Benih cabai yang akan diberi perlakuan induksi terlebih dahulu direndam dalam air hangat selama \pm 4 jam. Perlakuan induksi dilakukan dengan merendam benih cabai tersebut dalam suspensi khamir C. tropicalis dengan kerapatan $10^{8} \mathrm{sel} / \mathrm{ml}$ selama 60 menit. Selanjutnya, benih diperam menggunakan kertas tissue steril lembab dan disimpan pada suhu ruang selama 12 jam. Benih direndam dalam akuades steril sebagai pengganti suspensi khamir untuk perlakuan kontrol.

Benih cabai yang telah diberi perlakuan khamir dan kontrol, selanjutnya disemai pada polibag ukuran $10 \times 15 \mathrm{~cm}$ yang berisi media semai ready mixed media "Fam Organic" yang merupakan campuran dari tanah, sekam bakar, cocopeat dan pupuk kascing. Setelah bibit berumur 5 minggu dipindah ke polibag berukuran 20x25 $\mathrm{cm}$ dan disiram kembali dengan suspensi khamir sebanyak $30 \mathrm{ml}$ per bibit (kerapatan $10^{8} \mathrm{sel} / \mathrm{ml}$ ). Komposisi media tanam yang digunakan adalah campuran tanah dengan pupuk kandang sapi dengan perbandingan 2:1. Pemeliharaan tanaman dilakukan dengan cara menyiram tanaman setiap hari dan pemberian pupuk. Pupuk yang digunakan adalah pupuk urea sebanyak $1 \mathrm{~g} /$ polibag $(200 \mathrm{~kg} / \mathrm{ha})$, Za sebanyak 2,25 g/polibag (450 kg/ha), SP 36 sebanyak 0,75/polibag $(150 \mathrm{~kg} / \mathrm{ha}), \quad \mathrm{KCl}$ sebanyak 0,75 g/polibag (150 kg/ha) (Setiadi, 2006).

\section{Inokulasi $C$. acutatum}

Inokulasi patogen dilakukan sesuai perlakuan masing-masing, inokulasi menggunakan patogen antraknosa $C$. acutatum dengan waktu inokulasi 3, 7, dan 10 hsp. Perlakuan inokulasi patogen C. acutatum dilakukan pada tanaman cabai sehat. Daun cabai sehat yang muda dilukai menggunakan jarum steril. Patogen diinokulasikan dengan meneteskan suspensi $C$. acutatum sebanyak $0,1 \mathrm{ml} /$ daun (kerapatan $10^{6}$ konidia $/ \mathrm{ml}$ ). Jumlah daun yang diinokulasi per tanaman adalah empat daun. Tanaman yang telah diinokulasi disungkup menggunakan kantong plastik.

\section{Pengamatan Pertumbuhan Tanaman}

Pengamatan terhadap pertumbuhan tanaman dilakukan terhadap tinggi tanaman cabai, jumlah daun, dan bobot kering tanaman. Tinggi tanaman diukur menggunakan penggaris mulai pangkal batang sampai tajuk tanaman tertinggi. Jumlah daun dihitung dari seluruh daun yang ada pada masing-masing sampel tanaman dalam perlakuan. Tinggi tanaman dan jumlah daun cabai diukur dan dihitung selama 3 kali pengamatan. Bobot kering tanaman diukur dengan mengoven sampel tanaman cabai perlakuan selama 2 hari. Pengamatan bobot kering tanaman dilakukan 1 kali pada akhir pengamatan. Data tinggi tanaman, jumlah daun, dan bobot kering tanaman dihitung keefektifannya terhadap kontrol, dengan menggunakan rumus sebagai berikut:

$$
\text { Eip }=\frac{l p-l k}{l p} \times 100 \%
$$

Eip $=$ Keefektifan pertambahan pertumbuhan tanaman

$l_{\mathrm{p}}=$ Pertumbuhan tanaman dengan perlakuan khamir

$l_{\mathrm{k}}=$ Pertumbuhan tanaman kontrol (+)

\section{Analisis Data}

Data hasil pengujian dianalisis dengan Analysis of Variance (ANOVA) dengan menggunakan program SPSS Versi 22.0 for windows. Jika terdapat pengaruh perlakuan maka dilakukan uji lanjut dengan Uji Jarak Berganda Duncan pada taraf nyata 5\%.

\section{HASIL DAN PEMBAHASAN}




\section{Pengaruh Perlakuan Induksi Resistensi $C$. tropicalis terhadap Tinggi Tanaman Cabai}

Perlakuan induksi resistensi menggunakan

khamir C. tropicalis dengan beberapa waktu inokulasi $C$. acutatum memengaruhi tinggi tanaman cabai berdasarkan analisis statistik pada pengamatan 11 minggu setelah perlakuan (msp), dan $12 \mathrm{msp}$. Perlakuan induksi $C$. tropicalis dengan waktu inokulasi patogen 7 hsp menyebabkan rata-rata tinggi tanaman yang berbeda nyata dengan kontrol (+) waktu inokulasi 7 hsp baik pada pengamatan 11 maupun 12 msp. Demikian juga dengan perlakuan induksi C. Tropicalis dengan waktu inokulasi patogen 10 hsp menyebabkan rata-rata tinggi tanaman yang berbeda nyata dengan kontrol $(+)$ waktu inokulasi 10 hsp (Tabel 1).

Rata-rata tinggi tanaman cabai pada pengamatan $5 \mathrm{msp}, 11 \mathrm{msp}$, dan $12 \mathrm{msp}$ dengan perlakuan induksi $C$. tropicalis memiliki rata-rata tinggi tanaman lebih tinggi dibandingkan dengan kontrol (+) maupun kontrol (-) (Tabel 1 dan Gambar 1). Rata-rata tinggi tanaman tertinggi baik pada pengamatan $11 \mathrm{msp}$ maupun pada $12 \mathrm{msp}$ terjadi pada perlakuan $C$. tropicalis dengan waktu inokulasi 10 hsp, dengan rata-rata tinggi tanaman berturutturut sebesar 65,73 cm dan 69,87 cm (Tabel 1).

Berdasarkan perhitungan nilai keefektifan peningkatan tinggi tanaman diketahui bahwa khamir C. tropicalis mampu meningkatkan tinggi tanaman cabai. Kemampuan meningkatkan tinggi tanaman cabai tertinggi terjadi pada perlakuan $C$. tropicalis dengan waktu inokulasi $7 \mathrm{hsp}$ yaitu sebesar $30,72 \%$ pada $11 \mathrm{msp}$ dan 30,22\% pada 12 msp (Tabel 1). Akan tetapi, nilai keefektifan peningkatan tinggi tanaman yang diperoleh tergolong rendah yaitu berkisar antara $0,30 \%$ sampai $30,72 \%$

Tabel 1. Rata-rata tinggi tanaman dan keefektifan peningkatan tinggi tanaman cabai dengan perlakuan induksi khamir C. tropicalis

\begin{tabular}{|c|c|c|c|c|c|c|}
\hline \multirow[t]{2}{*}{ Perlakuan } & \multicolumn{3}{|c|}{ Rata-rata tinggi tanaman $(\mathrm{cm})$ pada pengamatan } & \multicolumn{3}{|c|}{$\begin{array}{l}\text { Keefektifan peningkatan } \\
\text { tinggi tanaman (Eip) (\%) } \\
\text { pada pengamatan }\end{array}$} \\
\hline & $5 \mathrm{msp}$ & $11 \mathrm{msp}$ & $12 \mathrm{msp}$ & $5 \mathrm{msp}$ & $11 \mathrm{msp}$ & $12 \mathrm{msp}$ \\
\hline C. tropicalis, inokulasi $3 \mathrm{hsp}$ & 10,09 & $59,82 \mathrm{bc}$ & $62,65 \mathrm{bc}$ & 0,30 & 20,19 & 16,66 \\
\hline C. tropicalis, inokulasi $7 \mathrm{hsp}$ & 11,33 & $60,69 \mathrm{bc}$ & $64,90 \mathrm{bc}$ & 15,63 & 30,72 & 30,22 \\
\hline C. tropicalis, inokulasi $10 \mathrm{hsp}$ & 12,77 & $65,73 \mathrm{c}$ & 69,87 c & 7,95 & 23,92 & 22,42 \\
\hline Kontrol (+), inokulasi 3 hsp & 10,06 & $47,74 \mathrm{ab}$ & $52,21 \mathrm{~b}$ & - & - & - \\
\hline Kontrol (+), inokulasi 7 hsp & 9,56 & 42,05 a & 45,29 a & - & - & - \\
\hline Kontrol (+), inokulasi 10 hsp & 11,75 & $50,01 \mathrm{~b}$ & $54,20 \mathrm{~b}$ & - & - & - \\
\hline Kontrol (-) & 10,76 & $51,54 \mathrm{bc}$ & $55,81 \mathrm{~b}$ & - & - & - \\
\hline
\end{tabular}

Keterangan: msp: minggu setelah perlakuan induksi penyiraman

Pengaruh Perlakuan Induksi Resistensi C. tropicalis terhadap Jumlah Daun

Berdasarkan hasil analisis statistik perlakuan induksi C. tropicalis berpengaruh terhadap jumlah daun tanaman cabai. Seluruh perlakuan induksi dengan waktu inokulasi yang berbeda menyebabkan rata-rata jumlah daun yang berbeda nyata dengan kontrol baik kontrol $(+)$ maupun kontrol (-) (Tabel 2). Rata-rata jumlah daun tanaman cabai yang diberi perlakuan induksi dengan khamir C. tropicalis menunjukkan jumlah daun yang lebih banyak dibandingkan kontrol baik kontrol (+) maupun kontrol (-) (Tabel 2). Perlakuan C. tropicalis dengan waktu inokulasi patogen $3 \mathrm{hsp}$ menghasilkan rata-rata jumlah daun terbanyak yaitu 47,5 daun. Perlakuan C. tropicalis dengan waktu inokulasi patogen 10 hsp juga menghasilkan ratarata jumlah daun yang cukup banyak yaitu 46 daun. Rata-rata jumlah daun paling sedikit dihasilkan pada tanaman kontrol yaitu antara 24 sampai 28,5 daun (Tabel 2).

Perlakuan C. tropicalis dengan waktu inokulasi 3 hsp memiliki nilai keefektifan peningkatan rata-rata jumlah daun tertinggi yaitu sebesar $49,47 \%$ (Tabel 2). Hal ini berarti khamir C. tropicalis dengan inokulasi patogen $3 \mathrm{hsp}$ mampu meningkatkan jumlah daun tanaman cabai sebesar $49,47 \%$. Nilai keefektifan peningkatan jumlah daun ini lebih tinggi dibandingkan dengan nilai keefektifan peningkatan tinggi tanaman. Nilai keefektifan peningkatan jumlah daun berkisar antara 32,05\% sampai 49,47\%. 


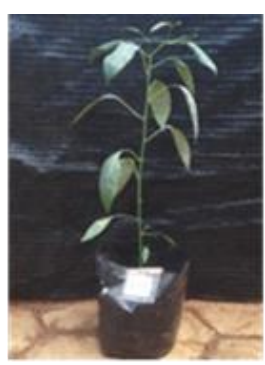

a

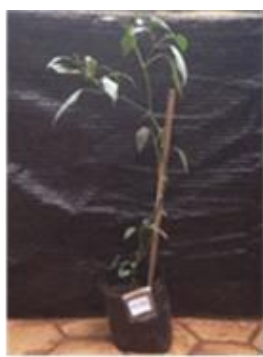

b

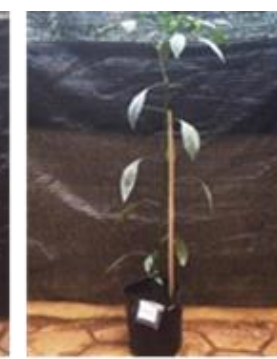

c

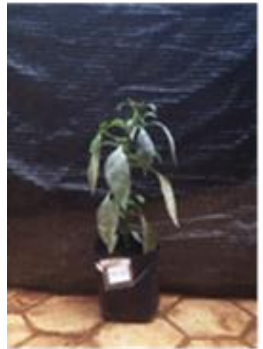

d

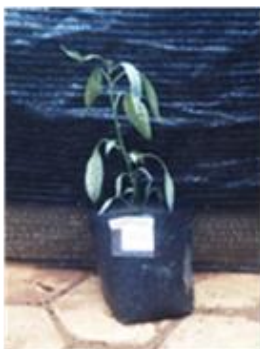

e

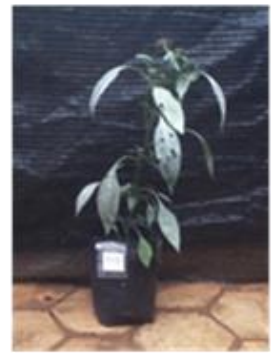

f

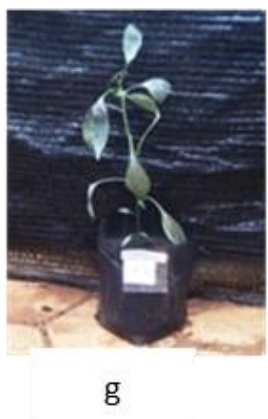

Gambar 1. Pertumbuhan tanaman cabai dengan perlakuan induksi resistensi pada umur tanaman 8 minggu a. C. tropicalis, 3 hsp; b. C. tropicalis, 7 hsp; c. C. tropicalis, 10 hsp; d. kontrol (+), 3 hsp; e. kontrol (+), 7 hsp; f. kontrol (+), 10 hsp; g. kontrol (-)

Tabel 2. Rata-rata jumlah daun dan keefektifan peningkatan jumlah daun tanaman cabai dengan perlakuan induksi khamir C. tropicalis pada umur tanaman 10 minggu

\begin{tabular}{lcc}
\hline \multicolumn{1}{c}{ Perlakuan } & Rata-rata jumlah daun & Keefektifan peningkatan jumlah daun (Eip) (\%) \\
\hline C. tropicalis, inokulasi 3 hsp & $47,50 \mathrm{~b}$ & 49,47 \\
C. tropicalis, inokulasi 7 hsp & $39,00 \mathrm{~b}$ & 32,05 \\
C. tropicalis, inokulasi 10 hsp & $46,00 \mathrm{~b}$ & 38,04 \\
Kontrol (+), inokulasi 3 hsp & $24,00 \mathrm{a}$ & - \\
Kontrol (+), inokulasi 7 hsp & $26,50 \mathrm{a}$ & - \\
Kontrol (+), inokulasi $10 \mathrm{hsp}$ & $28,50 \mathrm{a}$ & - \\
Kontrol (-) & $25,30 \mathrm{a}$ & - \\
\hline
\end{tabular}

Pengaruh Perlakuan Induksi Resistensi C. tropicalis terhadap Bobot Kering Tanaman

Berdasarkan hasil analisis statistik perlakuan induksi $C$. tropicalis tidak berpengaruh terhadap bobot kering tanaman. Akan tetapi, pengamatan terhadap bobot kering tanaman diketahui bahwa perlakuan induksi resistensi menggunakan khamir $C$. tropicalis mampu meningkatkan rata-rata bobot kering tanaman. Perlakuan induksi resistensi dengan C. tropicalis menghasilkan rata-rata bobot kering tanaman tertinggi yaitu berkisar antara 8-11 g/tanaman. Rata-rata bobot kering tanaman pada kontrol hanya berkisar antara 3-9 g/tanaman (Tabel 3).

Apabila dilihat dari nilai keefektifan peningkatan bobot kering tanaman, nilai keefektifan tertinggi terjadi pada perlakuan $C$. tropicalis dengan waktu inokulasi 3 hsp yaitu sebesar 50\%. Hal ini menunjukkan bahwa $C$. tropicalis mampu meningkatkan bobot kering tanaman sebesar 50\% (Tabel 3).

Bobot kering merupakan salah satu parameter untuk menganalisis pertumbuhan tanaman. Hal ini disebabkan karena $90 \%$ bahan kering tanaman adalah hasil fotosintesis (Goldsworth \& Fisher, 1984). Oleh karena itu, laju pertumbuhan vegetatif tanaman dapat diketahui melalui bobot kering tanaman. Beberapa faktor dapat mempengaruhi bobot kering dan tinggi tanaman seperti perlakuan pupuk N (Subhan \& Nikardi, 1998) dan mikrob. 
Tabel 3. Rata-rata bobot kering tanaman dan keefektifan peningkatan bobot kering tanaman cabai dengan perlakuan induksi khamir C. tropicalis pada umur tanama 10 minggu

\begin{tabular}{lcc}
\hline \multicolumn{1}{c}{ Perlakuan } & $\begin{array}{c}\text { Rata-rata bobot kering tanaman } \\
(\mathrm{g} / \tan )\end{array}$ & $\begin{array}{c}\text { Keefektifan peningkatan bobot } \\
\text { kering }\end{array}$ \\
\hline C. tropicalis, inokulasi 3 hsp & 6,00 & 50,00 \\
C. tropicalis, inokulasi 7 hsp & 6,00 & 0,00 \\
C. tropicalis, inokulasi 10 hsp & 7,00 & $-28,57$ \\
Kontrol (+), inokulasi 3 hsp & 3,00 & - \\
Kontrol (+), inokulasi 7 hsp & 6,00 & - \\
Kontrol (+), inokulasi 10 hsp & 9,00 & - \\
Kontrol (-) & 3,67 & - \\
\hline
\end{tabular}

Mikrob dapat memacu pertumbuhan tanaman baik secara langsung maupun tidak langsung. Pertumbuhan tanaman dipicu oleh mikrob secara langsung dengan menghasilkan zat pengatur tumbuh atau meningkatkan ketersediaan nutrisi yang terbatas untuk pertumbuhan tanaman (Waqas et al., 2012). Mikrob juga memicu pertumbuhan tanaman secara tidak langsung yaitu melalui penekanan gangguan patogen terhadap tanaman (Manici et al., 2014).

Beberapa bakteri dan jamur dilaporkan mampu meningkatkan pertumbuhan tanaman. Bakteri dan jamur antagonis yang telah dilaporkan sebagai pemicu pertumbuhan tanaman diantaranya Pseudomonas fluorescens strain CHA0 (Almario et al., 2014), Bacillus subtilis (Wang et al., 2010), Trichoderma spp. (Sundaramoorthy \& Balabaskar, 2013), dan Ampelomyces quisqualis (Dominic \& Marthamakobe, 2017).

Bakteri pemacu pertumbuhan tanaman menginduksi pertumbuhan tanaman melalui produksi berbagai macam senyawa organik (Mabood et al., 2014). Bakteri ini mampu meningkatkan nutrisi untuk mempengaruhi pertumbuhan tanaman secara langsung dan mengendalikan OPT (Hanudin et al., 2018). Bakteri pemacu pertumbuhan tanaman juga dapat memproduksi fitohormon seperti auksin, sitokinin, giberelin, dan etilen, yang berperan dalam pembentukan akar lateral dan rambut akar untuk meningkatkan penyerapan unsur hara dan air (Hanudin et al., 2018).

Peningkatan tinggi tanaman cabai dengan perlakuan induksi resistensi oleh khamir C.tropicalis dapat disebabkan oleh hormon pertumbuhan yang dihasilkan khamir tersebut. Hormon pertumbuan Indole-3-Acetic Acid (IAA) dapat dihasilkan oleh khamir Aureobasidium pullulans (Sun et al., 2014; Ignatova et al., 2015), Rhodotorula minuta (Nassar et al., 2005), Cryptocococcus flavus (Naratat et al.,
2014), Saccharomyces, Cryptococcus, dan Candida (Lasmini, 2016). Khamir Williopsis saturnus dilaporkan dapat menghasilkan Indole-3-Pyruvic Acid (IPYA) sebagai metabolit sekunder yang berperan dalam peningkatan pertumbuhan tanaman (Nassar et al., 2005). Senyawa IAA dan IPYA merupakan fitohormon yang paling umum diketahui berperan dalam pertumbuhan dan perkembangan tanaman (Teale et al., 2006).

\section{SIMPULAN}

Perlakuan induksi resistensi oleh khamir $C$. tropicalis mampu meningkatkan tinggi tanaman cabai dengan peningkatan tertinggi sebesar 30,72\% pada perlakuan $C$. tropicalis dengan waktu inokulasi 7 hsp. Peningkatan jumlah daun tertinggi terjadi pada perlakuan $C$. tropicalis dengan inokulasi patogen 3 hsp sebesar 49,47\%. Peningkatan bobot kering tertinggi terjadi pada perlakuan $C$. tropicalis dengan waktu inokulasi 3 hsp sebesar 50\%.

\section{UCAPAN TERIMAKASIH}

Ucapan terimakasih disampaikan kepada Direktorat Riset dan Pengabdian Kepada Masyarakat dan Inovasi Universitas Padjadjaran yang telah mendanai kegiatan ini melalui Riset Fundamental Unpad Program Hibah Internal Universitas Padjadjaran Tahun Anggaran 2018.

\section{DAFTAR PUSTAKA}

Al-Ani, A Rakib, MA Athab, and ON Matny. 2013. Management of Potato Virus Y (PVY) in potato by some biocontrol agents under field conditions. Environmental Biology. 7(3): 441-444.

Almario, J, D Muller, G Défago, and Y Moënne- 
Loccoz. 2014. Rhizosphere ecology and phytoprotection in soils naturally suppressive to thielaviopsis black root rot of tobacco. Environmental Microbiology. 16(7):1949-1960.

Badan Pusat Statistik dan Direktorat Jenderal Hortikultura. 2018. Produktivitas cabai besar. Tersedia online pada www.pertanian.go.id/ Data5tahun/HortiATAP Produktivitas\%20Cabai\%20 2017(.pdf)/ Diakses 25 Februari 2019.

Dominic, M, and M Marthamakobe. 2016. Biological control of cashew powdery mildew using Ampelomyces quisqualis Ces. Journal of Biological Control. 30(4): 226-235.

Goldsworth, PR, dan NM Fisher. 1984. Fisiologi Tanaman Budidaya Tropik. Gajah Mada University Press, Yogyakarta. Terjemahan.

Haïssam, JM. 2011. Pichia anomala in biocontrol for apples: 20 years of fundamental research and practical application. Antonie van Leeuwenhoek. 99: 93-105.

Hanudin, K Budiarto, dan B Marwoto. 2018. Potensi beberapa mikroba pemacu pertumbuhan tanaman sebagai bahan aktif pupuk dan pestisida hayati. Jurnal Litbang Pertanian. 37(2): 59-70.

Hartati, S. 2016. Khamir sebagai Agens Biokontrol Antraknosa (Colletotrichum acutatum J. H. Simmonds) pada Cabai Pascapanen. [Disertasi]. Sekolah Pascasarjana Institut Pertanian Bogor. Bogor.

Ignatova, LV, YV Brazhnikova, RZ Berzhanova, and TD Mukasheva. 2015. Plant growthpromoting and antifungal activity of yeasts from dark chesnut soil. Microbiological Research. 175: 78-83.

Kementerian Pertanian. 2015. Deskripsi cabai varietas Unpad CB-2. Surat Keputusan Menteri Pertanian Nomor 032/Kpts/SR.120/ D. $2.7 / 3 / 2015$.

Lasmini, T. 2016. Isolasi dan identifikasi khamir penghasil asam indol asetat dari rhizosfer anggrek tanah Pecteilis susannae (L.) Rafin. Jurnal IPTEKS Terapan Research of Applied Science and Education. 9(4): 261-268.

Mabood, F, X Zhou, and DL Smith. 2014. Microbial signaling and plant growth promotion. Canadian Journal of Plant Science. 94(6): 1051-1063.

Manici, LM, M Kelderer, F Caputo, and M Mazzola. 2014. Auxin-mediated relationships between apple plants and root inhabiting fungi: Impact on root pathogens and potentialities of growth-promoting populations. Plant Pathology. 64(4):851-43.

Nantawanit, N, A Chanchaichaovivat, B Panijpan, and $\mathrm{P}$ Ruenwongsa. 2010. Induction of defense response against Colletotrichum capsici in chili fruit by the yeast Pichia guilliermondii strain R13. Biological Control. 52:145-152.

Naratat, P, N Srisuk, P Arunrattiyakorn, and S Limtong. 2014. Plant growth-promoting traits of epiphytic and endophytic yeasts isolated from rice and sugar cand leaves in Thailand. Journal Fungal Biology. 118(8): 683-694.

Narusaka, M, T Minami, C Iwabuchi, T Hamasaki, S Takasaki, K Kawamura, and Y Narusaka. 2015. Yeast cell wall extract induces disease resistance against bacterial and fungal pathogens in Arabidopsis thaliana and Brassica crop. PLoS ONE. 10(1):1-14.

Nassar, H Amr, KA El-Tarabily, and K Sivasithamparam. 2005. Promotion of plant growth by an auxin-producing isolate of the yeast Williopsis saturnus endophytic in maize (Zea mays L.) roots. Biology and Fertility of Soils. 42(2): 97-108.

Setiadi. 2006. Bertanam cabai. Penebar Swadaya, Jakarta.

Sharma, RR, D Singh, and R Singh. 2009. Biological control of postharvest diseases of fruits and vegetables by microbial antagonists. Biological Control. 50(3): 205-221.

Subhan, AH, dan G Nikardi. 1998. Penggunaan pupuk nitrogen dan pupuk kandang ayam pada tanaman cabai di lahan kering. Jurnal Hortikultura. 9(2): 1178-1181.

Sundaramoorthy, S, and P Balabaskar. 2013. Biocontrol efficacy of Trichoderma spp. against wilt of tomato caused by Fusarium oxysporum f.sp. lycopersici. Journal of Applied Biology \& Biotechnology. 1(3): 3640.

Sun, PF, WT Fang, LY Shin, JY Wei, SF Fu, and JY Chou. 2014. Indole-3 acetic acid-producing yeasts in the phyllosphere of the carnivorous plant Drosera indica L. PLoS ONE. 9(12): 1-22.

Syukur, M, S Sujiprihati, R Yunianti, dan DA Kusumah. 2011. Pendugaan ragam genetik dan heritabilitas karakter komponen hasil beberapa genotipe cabai. Jurnal Agrivigor. 
10(2): 148-156.

Teale, WD, IA Paponov, and K Palme. 2006. Auxin in action: Signalling, transport and the control of plant growth and development. Nature Reviews Molecular Cell Biology. 7: 847- 859.

Wang, Y, Z Xu, P Zhu, Y Liu, Z Zhang, Y Mastuda, and $\mathrm{L} \mathrm{Xu.} \mathrm{2010.} \mathrm{Postharvest} \mathrm{biological}$ control of melon pathogens using Bacillus subtilis EXWB1. Journal of Plant Pathology. 92(3): 645-652.

Waqas, M, ALKhan, M Kamran, M Hamayun, SM Kang, YH Kim, and IJ Lee. 2012. Endophytic fungi produce gibberellins and indoleacetic acid and promotes host-plant growth during stress. Molecules. 17: 1075410773. 